YEARBOOK of ANTITRUST and REGULATORY STUDIES www.yars.wz.uw.edu.pl
Peer-reviewed scientific periodical, focusing on legal and economic issues of antitrust and regulation. Creative Commons Attribution-No Derivative Works 3.0 Poland License.

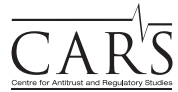

Centre for Antitrust and Regulatory Studies, University of Warsaw, Faculty of Management www.cars.wZ.uw.edu.pl

\title{
Compensation of Damages in Standalone Cases: Lessons to Be Learned from a Case Against a State-owned Telecommunication Company. Case Comment to the Judgment of the Lithuanian Court of Appeal of 3 March 2017 (Case No. e2A-27-464/2017)
}

by

Rasa Zaščiurinskaitė*

\section{CONTENTS}

I. Introduction

II. Essence of the dispute

III. Decision of the Competition Council of Lithuania

IV. Judgment of the court of first instance

V. Judgment of the appellate court: significance and lessons

to be learned

VI. Conclusions

Key words: damages, private enforcement; abuse; competition law; sector-specific regulation; refusal to supply; essential facilities; competition law.

JEL: K13; K21; K23; K41; K42

* Attorney specializing in EU and national competition law having litigation experience in most of private antitrust enforcement cases in Lithuania; actively participates as a contributor in conferences related to EU and national competition law including private enforcement; e-mail: Rasa.Zasciurinskaite@gmail.com. Article received: 17.08.2017; accepted: 31.08.2017. 


\section{Introduction}

Private enforcement in Lithuania is still at the early development stage, as only a few infringement decisions of the national competition authority the Competition Council of the Republic of Lithuania - have been followed on by private antitrust claims. Nevertheless, it might be observed that victims of competition law infringements tend to initiate standalone claims for compensation of damages in Lithuania. However, not all of those cases are successful.

On 3 March 2017, the Court of Appeal of Lithuania rejected a damages claim for EUR 2.9 million brought by a company that claimed to have been refused infrastructure access (an essential facility) by the dominant stateowned telecommunication company; infrastructure access was necessary for the provision of its own services. The case is interesting and worth mentioning due to the complexity and interrelation of competition law ${ }^{1}$ and the regulation of electronic communications (such as the interrelation of dominance in competition law and significant market power under the regulatory framework). The case is also noteworthy becaouse of the lack of involvement by the Competition Council and the Communication Regulatory Authority as well as their position in the dispute. Of relevance is also a change made to the laws related to the dispute and further consequences of the dispute.

This paper discusses the implications of the judgment of the Court of Appeal for further private enforcement in Lithuania, especially for the standalone cases. It first explores the background and essence of the dispute, actions taken by the parties to the dispute as well as the decision of the Competition Council (Part II and Part III). Discussed later on is the outcome and argumentation of the courts judgments as well as the significance of the judgment of the Court of Appeal and finally, lessons to be learned for future litigants and national courts (Part IV and Part V).

\section{Essence of the dispute}

In 2012, a consortium of three companies - UAB SATV network (hereinafter, SATV network), UAB Toptronas and UAB Bitè Lietuva -

${ }^{1}$ Even though the case related to the alleged violation of national competition law (Article 7 of the Law on Competition of the Republic of Lithuania) this case and interpretation of the court might be useful for the cases related to the EU competition law as Article 7 of the Law on Competition is equivalent national provision to Article 102 of the Treaty on the Functioning of the European Union (hereinafter, TFEU). 
participated in public procurement organized by the Lithuanian public broadcaster - Lithuanian National Radio and Television (hereainafter, LRT) - regarding the provision of broadcast transmission services for LRT TV programmes. The consortium has won the public procurement and concluded a services agreement with LGT for the period of 10 years. By way of the services agreement, a member of the consortium - SATV network - has been obliged to install a digital terrestrial TV network and from April 2013 to commence the provision of broadcast transmission services for LRT TV programmes.

As SATV network did not possess the infrastructure required for the provision of the transmission services, it applied for access to such infrastructure to the Lithuanian Radio and Television Centre (hereinafter, Telecentre). Telecentre is a state-owned joint-stock company engaged in the provision of radio and television programme transmission, TV broadcast transmission, data transmission as well as Internet and telephony services throughout Lithuania. As SATV network and Telecentre had not reached an agreement regarding the terms for the access to the infrastructure (mainly the prices), and due to delays in their negotiations, SATV network failed to installed the required digital terrestrial TV network and has not commenced the provision of services to LRT within the terms agreed by the parties under the services agreement. Therefore, in December 2013, LRT informed SATV network of the termination of the services agreement.

SATV network consequently has lodged a private enforcement claim before Vilnius Regional Court for the compensation of damages amounting to EUR 2.9 million, as well as a $6 \%$ annual procedural interest to be calculated from the awarded amount. The damages were calculated in the form of lost profit for the period of the whole expected validity of the services agreement (that is, 10 years).

\section{Decision of the Competition Council of Lithuania}

Before the termination of the services agreement with LRT in 2013 SATV network applied to the Lithuanian Competition Council regarding the initiation of an investigation against Telecentre for the refusal to grant access to its infrastructure which would constitute an abuse of its dominant position and a violation of Article 7 of the Law on Competition (equivalent to Article 102 TFEU). SATV network claimed that due to Telecentre's refusal to grant infrastructure access, SATV network could not commence the provision of the transmission services to LRT. 
By Resolution No 1S-151 of 29 October 2013, the Competition Council commenced an investigation of the alleged abuse of dominance by Telecentre. However, on 10 March 2015, the Competition Council adopted Resolution No $1 \mathrm{~S}-25 / 2015^{2}$ whereby the Competition Council terminated the investigation due to the following reasons.

In July 2014, the Law on Lithuanian National Radio and Television (hereinafter, the Law) was amended whereby Telecentre was granted exclusive rights to provide the above-indicated transmission services to LRT due to national security interests. ${ }^{3}$ It is noteworthy that the amendments were adopted irrespective of their criticism by the Lithuanian Competition Council ${ }^{4}$ and the European Law Department under the Ministry of Justice. ${ }^{5}$ Both bodies were concerned that the granting of exclusive rights to Telecentre by way of the amendments to the Law might have been in breach of EU law.

Considering the fact that the Law granted exclusive rights to Telecentre to provide transmission services, the Competition Council recognised that further investigation of Telecentre's refusal to grant access to its infrastructure for the provision of services exclusively assigned to Telecentre by the Law, would not comply with the priorities of the Competition Council, as further investigation would not contribute to effective competition and consumers' protection. Paradoxically therefore, the Competition Council terminated the investigation due to a Law which the Competition Council has itself criticized as possibly being in breach of competition rules. Nevertheless, the Competition Council emphasized in its Resolution No 1S-25/2015 that the decision to terminate

2 Resolution No. 1S-25/2015 of the Competition Council dated 10.03.2015. Retrieved from: http://kt.gov.lt/lt/dokumentai/del-akcines-bendroves-lietuvos-radijo-ir-televizijos-centroveiksmu-atitikties-lietuvos-respublikos-konkurencijos-istatymo-7-straipsnio-reikalavimamstyrimo-nutraukimo (16.08.2017).

3 As it was indicated in the Explanatory Note to the draft Law, such an amendment has been inspired by the fact that the private service provider [that is, the claimant] had failed to perform its contractual obligatons towards LRT and, consequently, a digital terrestrial TV network has not been installed. Therefore, considering national security interests, Telecentre should be granted such rights as the company of strategical importance to national security under the laws. See Explanatory Note to the draft Law amending Article 5 of the Law on Lithuanian National Radio and Television No. XI-1574 dated 14.03.2014. Retrieved from: https://eseimas.1rs.lt/portal/legalAct/lt/TAK/42471a22ab5611e39054dc0fb3cb01ae?jfwid=p60bc0lv (16.08.2017).

${ }^{4}$ Letter No. (2.30-25) 6V-399 of the Lithuanian Competition Council dated 03.03.2014. Retrieved from: https://lrv.lt/uploads/main/Posed_medz/2014/140312/19.pdf (16.08.2017), p. 11-12.

5 Letter of the European Law Department under the Ministry of Justice of the Republic of Lithuania dated 27.03.2014. Retrieved from: https://e-seimas.lrs.lt/portal/legalAct/lt/TAK/f14f3 730b5b711e3b2cee015b961c954?jfwid=p60bc0lv0 (16.08.2017). 
the investigation does not mean that the actions of the undertaking being investigated could not have infringed the Law on Competition.

SATV network has logded a claim before Vilnius Regional Administrative Court disputing the Resolution NO 1S-25/2015 of the Competition Council. However, the claim has not been accepted because it had certain formal defects and consequently, due to the failure to correct these defects within the legelly prescribed time limits. ${ }^{6}$

As a result, the damages claim lodged by SATV network before the Vilnius Regional Court should be regarded as a standalone claim whereby SATV network, as the claimant, was obliged to prove the violation of competition rules as well as other elements of the civil liability of Telecentre (except for fault, which is presumed following Article 6.248 of the Civil Code of the Republic of Lithuania). ${ }^{7}$ It is noteworthy that the claimant has based its position regarding Telecentre's dominance in the relevant market and its abuse of that dominance inter alia on the decisions of the Communications Regulatory Authority of the Republic of Lithuania (hereinafter, CRA), as further discussed in Part IV and Part V.

\section{Judgment of the court of first instance}

Vilnius Regional Court as the court of first instance by its judgment dated 25 January 2016 dismissed the claim of SATV network. The court based its judgment on the following grounds: (i) the infrastructure of Telecentre necessary for the performance of the services agreement with LRT has been substitutable and Telecentre did not hold a dominant position here; (ii) CRA Dispute Commision by its decision dated 30 October 2013 recognised that Telecentre has not refused access and was ready to grant access to its infrastructure to the claimant; (iii) Telecentre had no economic interest in refusing to grant access, as Telecentre would in any event receive income either directly from LRT (if the public procurement had been won by Telecentre) or indirectly - from the claimant (if the claimant and other consortium members provided the services to LRT using Telecentre's infrastructure); (iv) the fact that prices offered by Telecentre for access to its infrastructure were higher than expected by the claimant could not be regarded as a refusal

${ }^{6}$ Even though it has been appealed by SATV network; Supreme Administrative Court of Lithuania by its ruling dated 10.08.2015 in administrative case No eAS-1050-520/2015 dismissed the claim of SATV network.

7 Judgment of the Supreme Court of Lithuania dated 17.05.2010 in the civil case No. 3K-3$207 / 2010$. 
to grant access; (v) the claimant has not proven its financial ability to perform the services agreement with LRT, also the claimant did not prove its lost profit.

The motives of the Vilnius Regional Court regarding Telecentre's lack of dominance on one hand, and the aknowlegdment by the court that the claimant could provide the services only using Telecentre's infrastructure on the other hand, were quite contradictory. The court of first instance ignored other evidence substantiating Telecentre's dominance in the relevant market (for example, decision No. 1V-622 of the CRA dated 28 May 2015 whereby Telecentre has been recognised as having significant market power on the market for the provision of services of TV broadcast transmission via terrestrial networks) as well as other evidence proving the civil liability of Telecentre. Hence, the claimant appealed the judgment of the Vilnius Regional Court before the Court of Appeal of Lithuania.

\section{Judgment of the appellate court: significance and lessons to be learned}

By judgment dated 3 March 2017 (civil case No. e2A-27-264/2017) the Court of Appeal upheld the judgment of the court of first instance, i.e. dismissed the damages claim of SATV network. However, this judgment of the Court of Appeal is important for further development of the private enforcement in Lithuania for the following reasons as the case shall not be heard before the Supreme Court of Lithuania. ${ }^{8}$

Firstly, the Court of Appeal recognized that decisions of the CRA establishing the existence of significant market power on the relevant market of the undertaking (following the Law on Electronic Communication of the Republic of Lithuania ${ }^{9}$ ) may be regarded as prima facie evidence of the definition of the relevant market in terms of competition law and of dominance of that undertaking, at least in certain circumstances. Namely, the Court of Appeal disagreed with the position of the court of first instance and recognised that Telecentre held a dominant position on the relevant market based on the decision No. 1V-622 of the CRA dated 28 May 2015 whereby Telecentre has been recognised as having significant market power on the

8 The judgment was further appealed to the Supreme Court but the latter refused to accept the cassation claim due to lack of grounds for cassation.

9 The Law implemented Directive 2002/19/EC of the European Parliament and of the Council of 07.03.2002 on access to, and interconnection of, electronic communications networks and associated facilities. 
relevant market. ${ }^{10}$ This decision of the CRA was reviewed and confirmed by the Supreme Administrative Court of Lithuania by its ruling dated 7 January 2017 (administrative case No. A-2054-492/2016).

The Court of Appeal emphasized that even though the purposes and scope of the application of the Law on Competition and Law on Electronic Communication are different, the definition of significant market power under the Law on Electronic Communication may be regarded as similar to the definition of dominance under the Law on Competition, and so it may be used in competition cases as well. This judgment is in line with the recent jurisprudence of the Supreme Administrative Court of Lithuania. ${ }^{11}$ It also confirms, at least indirectly, that competition law and regulation may, and should coexist. Hence, even though the aforementioned decisions of the CRA would not have had binding effect in the same way as infringement decisions of the Competition Council (following the Damages Directive ${ }^{12}$ and Law on Competition of the Republic of Lithuania), the prima facie evidential value of the CRA's decisions will also be crucial for claimants, especially in standalone private antitrust cases against undertakings active in such regulated sectors as electronic communications, energy, etc.

Secondly, even though the Court of Appeal was also reluctant to perform a more effect-based evaluation of the behaviour of Telecentre, and consequently found no abuse of dominance by Telecentre, the argumentation of the Court of Appeal was more explicit compared to the judgment of the court of first instance. It might be discussed if the findings of the appellate court are correct and substantiated, especially where the court itself recognised that 'there might be elements of the abuse' of Telecentre dominance by bundling its services to the claimant and refusing to separate them. However, the court did not perform a further analysis and did not use any effect-based argumentation. However, certain lessons might be learned from the judgment for future litigants and national courts as well.

The Court of Appeal based its findings mainly on the decision of the CRA Dispute Commission, dated 30 October 2013, whereby the Commission has not found that Telecentre discriminated the claimant by applying different price conditions compared to its other clients. Even though the claimant appealled the decision of the Commission, it has later withdrawn the appeal,

\footnotetext{
10 Telecentre held $94.4 \%$ of the relevant market.

11 Judgment of the Supreme Administrative Court of Lithuania dated 07.01.2017 in the administrative case No. A-2054-492/2016.

12 Directive 2014/104/EU of the European Parliament and of the Council of 26.11.2014 on certain rules governing actions for damages under national law for infringements of the competition law provisions of the Member States and of the European Union Text with EEA relevance//OJ L 349, 5.12.2014, p. 1-19.
} 
a fact pointed out by the Court of Appeal in its judgment dated 3 March 2017. The court emphasized that the claimant has not submitted evidence substantiating the discrimination of the claimant as compared to companies being in analogous conditions (the amount of costs, scope of services, type of infrastructure used, etc.). It might be discussed whether the findings of the court would have changed if an economic expert was appointed in the case in order to evaluate the price conditions, or if the Competition Council was involved in the case as amicus curia. Sufficient access to evidence is also crucial in such a standalone private enforcement case.

Thirdly, the Court of Appeal recognized that the claimant itself did not act as bonus fater familias before the signing of the services agreement with LRT during the negotiations with Telecentre, which has been recognized by the court as the main reason for the termination of the services agreement. Consequently, no causal link between the behavior of Telecentre and the damages suffered due to the termination of the services agreement has been found by the court. It is quite difficult to evaluate from the judgment to what extent the claimant could have acted differently during the public procurement procedures and during the negotiations, especially considering the bargaining power of Telecentre, in order to act as bonus fater familias. However, it might be discussed if a more-balanced approach to the evaluation of the behavior of both the claimant and the defendant could have been taken by the court.

Fourthly, the court reiterated the criteria established by the case-law of the Supreme Court of Lithuania ${ }^{13}$ for the evaluation of lost profit as damages, i.e. (i) could the income have been foreseen in advance; (ii) could the income have been expected during normal activity; (iii) has the income not been received due to illegal actions of the defendant. Lost profit could be awarded only if it is proven to be real, rather than hypotethical. ${ }^{14}$ The Court rejected the quantification of damages presented by the claimant, which used the prices of another client of Telecentre for a different scope of services. Also, the Court of Appeal regarded that the claimant has not proven its economic ability to perform the services agreement with LRT. Also taken into account by the court in assessing the existence of damages were the fact that the claimant was established just before the commencement of the public procurement (as a vehicle to participate in the procurement and to implement the project), and that the claimant went into insolvency procedure after the services agreement was cancelled. It might be discussed whether, considering the circumstances, the above-indicated approach and argumentation used by the court would

13 Judgment of the Supreme Court dated 25.11.2016 in the civil case No. 3K-3-480-687/2016.

14 Judgment of the Supreme Court dated 22.05.2015 in the civil case No. 3K-3-306-916/2015. 
comply with the principles of effectiveness and full compensation of damages under the Damages Directive. However, it is also a good reminder that the quantification of harm is a complicated economic-based exercise both for the parties and the court where the role of economic experts is crucial (for the choice of a proper method for the quantification of harm, for substantiation of the relevant factors while quantifying the damages, for a substantiated quantification of harm, etc.).

The outcome of the case might have been different if the Competition Council had not terminated its investigation against Telecentre (or at least, if the case material of the Competition Council's investigaton could have been used in the civil case - it does not appear to be used in this case) due to the granting of exclusive rights to Telecentre by the amended Law, and if it had established that Telecentre commited an abuse, at least to certain extent. The investigation and findings of the Competition Council, which has broad powers to pursue the investigation, could have also helped to evaluate whether the behaviour of Telecentre during its negotiations with the claimant had not, in fact, led to the amendment of the Law, the adoption of which the Competition Council opposed. The outcome of the case migh have also been different if the legality of the Law granting the exclusive rights in question had been reviewed by the Constitutional Court of Lithuania (with respect to the compliance of the Law with Articles 29 and 46 of the Constitution of the Republic of Lithuania), by the European Commission, or by the Court of Justice of the European Union (with respect to the compliance of the Law with Articles $106^{15}$ and/or 107-108 TFEU).

\section{Conclusions}

This case is one of the examples how competition law might have worked in protecting the legitimate interests of competition law victims when regulatory authorities did not find, or were not eager to investigate and find a violation. Importantly, competition law could and should coexist in regulated sectors, in order to ensure better competition protection in such economic fields. The possibility to rely on findings of a national regulatory authority when substantiating complex elements of the abuse (such as definition of the relevant market, dominance in the relevant market and others), as acknowledged by the appellate court, is crucial for litigants in standalone cases. This case

15 See Case C-320/91 Corbeau, ECLI:EU:C:1993:198, para. 14; Case C-49/07 Motosykletistiki Omospondia Ellados NPID (MOTOE) v. Elliniko Dimosio, ECLI:EU:C:2008:376, para. 44. 
also shows what factors and circumstances are important for a successful private enforcement case, and what could have been done differently in order to make a success story out of standalone cases. It is expected that the additional instruments provided by the Law on Competition implementing the Damages Directive (such as better access to evidence, clearer rules for the quantification of harm, role of national courts in quantifying the harm and, in general, duty to follow the principles of effectiveness and full compensation under the Damages Directive), will help tackle existing obstacles for a better development of private antitrust enforcement in Lithuania. 